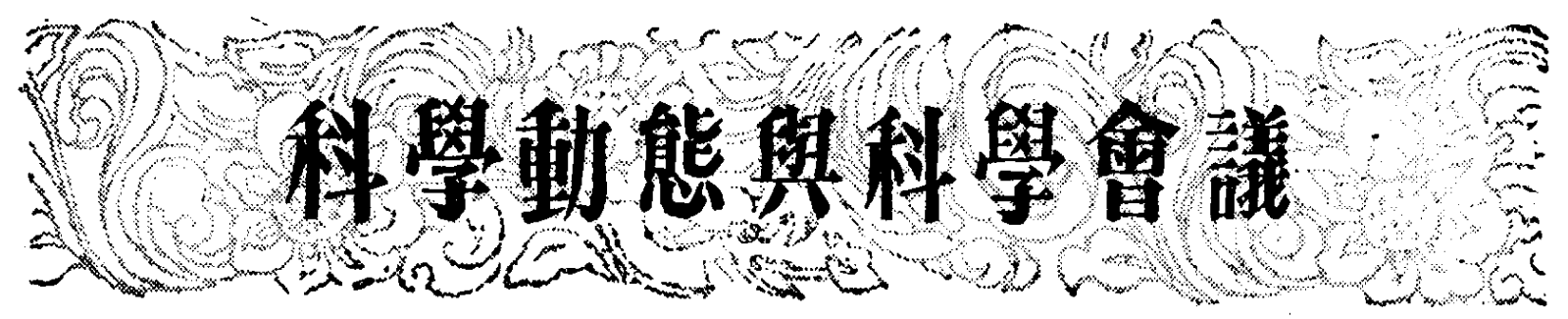

\title{
科學工作者對於學習蘇聯、發展 我國科學工作的意見（續）
}

\section{物理學座談會}

中國科學院訪蘇代表團錢三强團長作了有關 旗聯物理科學的成就與現况的報告之後, 在 1953 年 7 月 5 日科學院又邀請了各有關研究所、各高 等學校的物理學家和産業部門的代表開了一次座 談會, 討論應該怎㥞結合我國實際情况來學皙蘇 聯先淮經驗, 改進我國物理科學方面的工作。座 談會由舆有訓副院長主持。

在這一次座瓷會中比較集中地討論了四個問 題, 就是物理科學的發展方向問題、理諭聯系琠 際問題、科學工作的領導與組織問題和幹部培養 問題。

關於發展方向問題, 到會的學者們都一致视 筑中國物理學的發展首先應該服從國家需要, 北 京大學等鯍泰敉授舉蘇聯物理學家等干涉方法研 究金嚳表面作例子，說明了物理學的任一部門都 可以由於國家的需要而獲得發展, 絃典物理學也

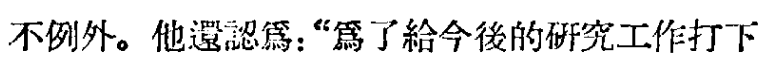
堅實的基礎, 經典物理學方而的研究是不應該被 淧就的。”

清菲大學錢偉長敉投在發言中認絾我們應該

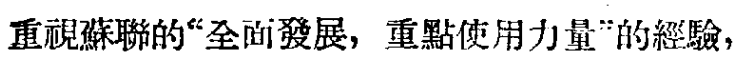
他說: “我們丕該把大部分力量放在發屡的重點 上，同時也應該用較少的力量在其他部門中播種 扎根, 雼將來進一步的發展作潐備。”在座談會上 大家一致認雼物理學政究的重點應該是原子核物 .理學、固體物理學和電子學, 而固體物理學的兩 㧽關鍵應該是金栨物理學和斗導體問題。

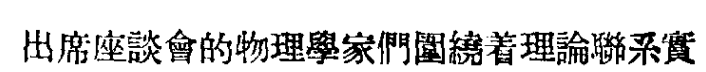
際問題作了熱烈的討論。應呞物理研究所陸學善 代理所受指出: “我們不僅要解决一些目前生產上.

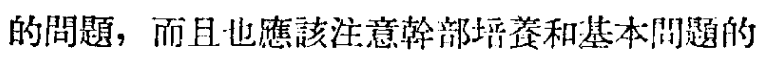
研究，一䨗長遠的科學與生碎部門的合作打好基 礎。”隹用物理硼究所滆研究是洪朝生說: “我們應

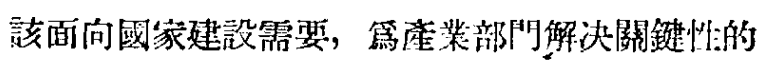

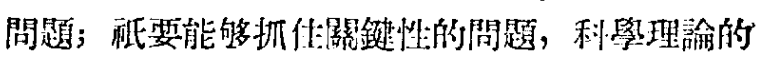
水本就一定會隨着閶題的解决而提高。”㤫用物理

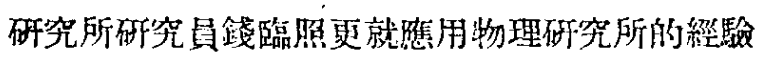
提出了一些應硋重視的問題, 他說: “去年牫們訂 計劃時, 由於不能正確地掌握理諭聯系汪際湸一 原則, 所以, 凡是與生產有些嚁聯的問題, 手們都 把它訂到訃劃之中。當時大家急於媱工業服務, 主觀願望不能淠不好, 但結果計劃犁得太大、太

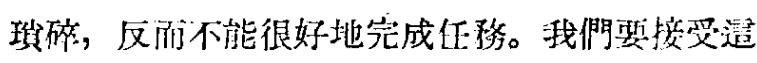

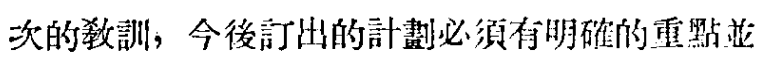
且必須是切镇可行的。”錢郜照先生還锁到與產業

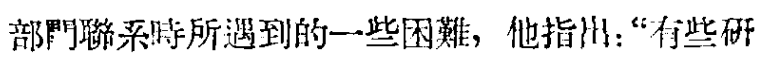

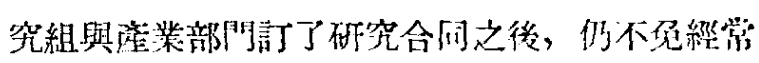

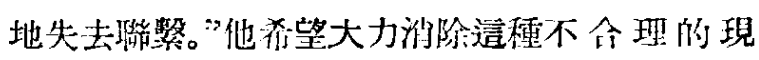

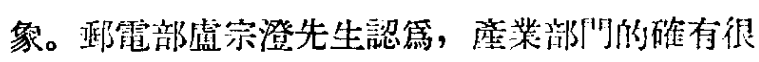
多閔鍵性問題需要科學院整助解决; 他以坫等悲 置規籍問題和定向天綫問題篇例，說明了售此阙 鍵性問題事筫上也旁涉到很基本的理涂閏题。

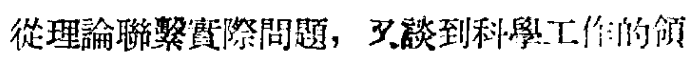

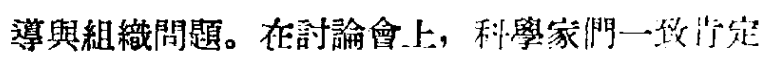


全國科學砾究工作必須由科學院來領導，並且還 提出了很多具體的建議。大家認窟: 過去學校、 企業、㸴究部門各搞一套, 浪費了不少力量, 今 後乔望有一個統一的領導; 科學院應該負起領導 的責任, 充分地掌握各方面的情况, 確定工作的 方向和重點, 訂出全耐的工作計劃, 使大家步調 一致起隶。

在座談會上, 大家對於幹部培養問題和科學 院與大學間的工作配合問題也提出了很多意見。 錢偉長敎授指出, 大學普通物理敎學首先必須貫 徹唯物主義敉學的目的, 因此提高已有敉學幹部 的馬克思列寧主義思想水本是十分重要的。他還 詮: “幹部要在實驗室裹生長起來, 應該着重實驗 物理學, 培錅脚踏實地的作風。” 北京大學周境源 敉授乔望科學院和高敉部的領導上能狗學栶葆聯 的辦法，在整體的精神下作適當的安排，使科學 工作者既能作敉學工作, 又能作研究工作。錢偉
長敉授還指出: “招生問題對於幹部培䒅也十分重 要，但是過去大家都没有重視這個問題; 敉育部

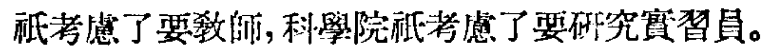
事實上物理學是基礎科學，各部門都需要，以後 招生必須全面地考虑各方行的需要, 也應該徵求

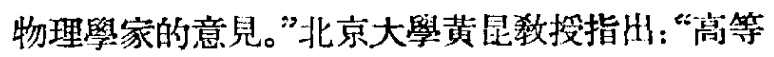
學校的院系調整是培费幹部的重要措施, 计㨁接 與科學院的幹部問題有關，但是科學院對於院系 調整不够重視。明年大學裹又要有 '專門化' 措 施, 可是科學院在訂五敦劃時, 對這問題似 乎也没有過問。”北京大學栠企係呚授着重地 提 出, 科學院應該注意那些大學有專門化, 專門化 是些什麼; 他認鹞對於大學專門化的指導是科學 院頚等重要的任務。到會的大學敉師們都一致認 篇必須取得科學院與産業部門的配合, 大學的培 荟物理學工作幹部的任移才能够完滿地完成。

\section{植物學座談 會}

1953年 7 月 10 日中國科學院邀請了農業部、 林業部、高等敎育部、北京農業大學、北京大學、 北京林學院、華北農業科學研究所、林業研究所 及中國科學院有閣植物方面的㸴究單位的代表共 28 人, 座談如何根據蘇聯在植物方面的先進經驗, 結合我國䐝際情况來㸴究我國植物學的發展方向 和有關問題。

會上大家根據蘇聯的先進經臨認爲植物學應 該更好地篇農業和林業建設以及其他有關國民經 濟發展的事業服務。由於我國過去植物學發展的 不平衡, 遠不能滿足國家經濟建設的要求, 第了 克服這種不本衡, 應該重點地發屡地椋物學、植 物生理學、林學等部門。第了提高科學水平, 以 後應注意有系統的研究工作。但在現在我國人力 物力不够的情况下, 應該把研究力量放在今天能 解决的問題上，並鴿今天不能解决的根本理論問 㩆有計劃地着手淮備。

對植物資源調笨問題，大家認営在國家大規 模經济建設中，植物資源的調查佔着重要的地位， 因此必須有系統地大力開展這一工作。應搜集全 國䭪食作物、牧草、果樹的品䅨和野生品種; 另
外尤其要注意工業原料植物資源調查和鋉食作物 的調查。工業原料方面應以木材、油料作物、樂 用植物、棫維作物篇重點。亚應把各項調圭研究 結果寫成各類手册和植物誌, 第國家經濟建設提

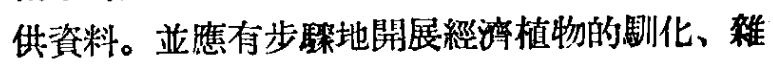
交、育種等工作。

大家認篇植物學工作者應該組織起來研究解 决農業生産上目前存在的嚴重問題, 例如棉花落 花落鈴、小麥凍害、洋㿈病害等。北京農業大學 敎授賈壃修提出了牧草問題, 認学牧草的研究, 還應該分析牧草所含成分和用途, 地植物學工作 者應該對我國牧草有一個全面的調查。林業方 面，林業部部長梁希特别提出西北水士保持和防 沙的造林問題, 認篇㮣該是植物學方话泊的一個重 要工作。由於基本建設的迅速發展，朴材的合理 利用、長期利用、防然、林水更新等, 都是植物 學結合林業研究單位的重要研究題目。

植物生理學方面, 北京農業大學敉授塤成後 在討論中指出過去植物生理學工作中㣂重用生长

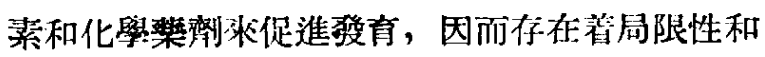
片面性。今後應注意研究植物的個體發育, 結合 
新陳代謝類型和其他方面的工作, 並要注意灌溉 生理、肥料生理等, 這些必須與微生物學和土壤學 結合研究。細胞生理也要結合膠體化學和生物化 學來做。光合作用是植物最主要的、基本的生活 過程之一，應該着重研究。

會上還專門討論了棕合性工作的問題。大家 認䉆植物學的研究應該與其他學科密切配合, 並 指出只有與其他學科密切配合，才能完成國家的 重大任務。例如西北水土保持工作，篇了保持水 土, 植物學須研究植被、造林、牧草等工作, 迢 些工作必須與土壤、林業、水利等學科相配合。 北京農業大學賈揁修認第研究牧草的工作就需要 植物學、土壤學、裁培學、畜牧學等學者共同進 行。中國科學院植物研究所副所長林鎔認䉆應把 各方面的科學家組織起來進行綜合性的專題研究 工作。

會上又討論了研究、敉學和産業部門加强聯

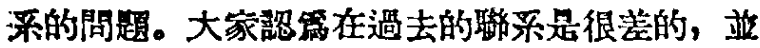

且存在着很多問题。例如中央高等教育部周家裁 塥到中南區的音牧以乳牛篇中心, 可是研究工作 的重點却是搞獊子人工授精。這些問題主要是工 作的目的不朋確。會上認篇今後可以成立工作委

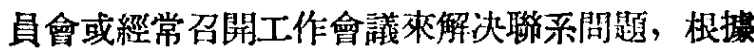
各個專門研究題目, 訂立整個研究計劃, 由中國 科學院估計各方面的力量和條件分工合作。

在植物學方面培羔幹部是一個重要問題, 研 究機關、學校和産業部門應該有計劃的進行，通 力合作。業務部門應指出培䓹的方向和提出業弱 上的要求。有關部門可以經常到學校中去做報告, 這樣對學生的學㚙會有所啓發。會上同時指出篇 了提高敉學質量, 敎師㗹多參加研究工作和其他 調查、勘察等工作。對於目前生物科學中保存的 空白部門，大家希望中國科學院能與學校合作， 設法逐步解决。

$$
\text { (本 刊) }
$$

\section{“使用多品種多標號水泥先進經驗推廣大會”介紹}

蘇聯的生產與使用水泥的科學, 是世界上最 先進的。在水泡品種方面, 蘇聯有十大䄚類, 五 一十餘種名䊈; 在標號方面, 則從 25 號直到 600 號。 㴆些水汁被庴泛地、合理地用在各種工程上，獲 得了優越的效果。在蘇聯還盛行着就地取材、在 工地搞入混合材料的辦法，經流而有效地服務於 洪座主義建設。我國在蘇聯專家沜助之下，兩年 濑在東北和華北生産㟫混合秋料水泥已取得了相 當的成就。在水泥品種方面, 我國現在巨有侈酸

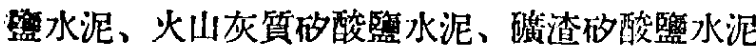
及混合低酸留水泥等四種。如果建設上需要，還 河以生產堵塞水泥（石油井用）及抗硫酸監水泥 等特殊品種的水泥。在標踋方面也分了 $200 、 300$ 、 4.00 及 500 等四個標號。如果工程上有特殊需要, 也可以生座 600 號的高標號水泥。

生產撸混合材料水泥有着巨大的經濟意義， 是水泥生産方面增産節約的最迅速、有效的乵法。 採取這種乵法祇須增加一些简單的粉嘛及烘乾設
備, 就可以利用廉價易得的礁產或工業廢料，大

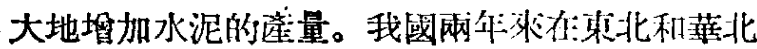

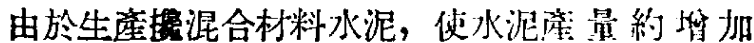
$25 \%$ ，其效果約相當增建三個大型水沉潡（新建 一個水泥廠需要投資數千偲，需時二、三年）；阔 時還降低了生產成本䄪 $10 \%$ ，用此项降低成本的 資金等年的叮建築 10 萬平方米的工人宿全。

另一方面，㟫混合材料水泥如果俅用得常，還 有着顯著的技衐效果。因第在矿酸監水泥中接入 混合材料，可以改善水泥的性能（如算加酎徒刢 性、酎水性、耐熟性、和易性以及減低水化熟 等), 可以調䇫水汇的標號以滿足各種性留工程的 需要。兩年來我國所生產的多品種多標號的水泥 已經大量地用於各種工程上。全國工業基地的歎

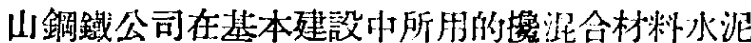

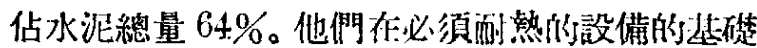

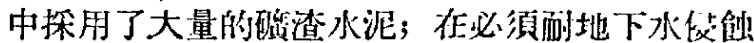

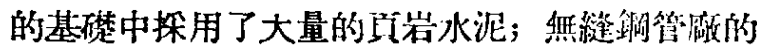

